\title{
EFFECTS OF SPRAYING ZINC FERTILIZER ON THE PHYSIOLOGICAL AND PHOTOSYNTHETIC CHARACTERISTICS OF MILLET PLANTS (SETARIA ITALICA L.) AT DIFFERENT GROWTH STAGES
}

\author{
CAO, M. L. ${ }^{1}-$ LI, Y. X. ${ }^{1}-$ DU, H. L..$^{2 *}$ \\ ${ }^{1}$ College of Agricultural Science, Shanxi Agricultural University, Taigu, Shanxi 030801, \\ People's Republic of China \\ ${ }^{2}$ College of Arts and Sciences, Shanxi Agricultural University, Taigu, Shanxi 030801, People's \\ Republic of China \\ *Corresponding author \\ e-mail: duhuiling66@163.com
}

(Received $1^{\text {st }}$ Feb 2019; accepted $16^{\text {th }}$ May 2019)

\begin{abstract}
Pot experiments were conducted from May 2017 to October of 2017 at the cultivation base of the Resource and Environment College of the Shanxi Agricultural University in China. The physiological and photosynthetic characteristics of different cultivars treated with different $\mathrm{Zn}$ concentrations at different growth stages were investigated to determine the optimum spraying period and spraying concentration of $\mathrm{Zn}$ fertilizer $\left(\mathrm{ZnSO}_{4} \cdot 7 \mathrm{H}_{2} \mathrm{O}\right)$ in Millet plants (Setaria italica L.). Results showed that spraying low $\mathrm{Zn}$ concentrations $\left(20,40\right.$, and $\left.60 \mathrm{mg} \cdot \mathrm{L}^{-1}\right)$ solutions decreased the malondialdehyde content, $\mathrm{Ci}$ (intercellular $\mathrm{CO}_{2}$ concentration), and $\mathrm{qN}$ (non-photochemical quenching coefficient) but increased antioxidant enzymatic activities, pigment content, photosynthetic gas exchange parameters (except $\mathrm{Ci}$ ), and chlorophyll fluorescence parameters (except qN). By contrast spraying high Zn concentration ( 80 and $100 \mathrm{mg} \cdot \mathrm{L}^{-1}$ ) showed opposite effects. Moreover, 'Jingu 21' (susceptible variety, conventional cultivar) showed more remarkable variation higher than 'Zhangzagu10' (resistant variety, hybrids). Thus, low Zn concentration promoted plant growth, while high $\mathrm{Zn}$ concentration inhibited plant growth, which was most pronounced during the Millet booting stage. The optimal conditions were booting period and $40 \mathrm{mg} \cdot \mathrm{L}^{-1}$ of $\mathrm{Zn}$. Thus, a theoretical basis for the efficient use of Zinc Fertilizer in Millet is provided.

Keywords: foxtail millet, growth stage, zinc fertilizer, antioxidant enzyme activity, photosynthetic gas exchange parameters, chlorophyll fluorescence parameters
\end{abstract}

\section{Introduction}

Zinc is an essential element in human health and an indispensable trace element in animal and plant growth (Gartler et al., 2013). As the only metal element to be simultaneously present in six enzymes, Zn plays an important regulatory role in plant photosynthesis, protein and nucleic acid metabolism, auxin metabolism, biofilm stability, and cell division (Prasad and Hagemeyer, 1999; Kabata-Pendias and Pendias, 2001). In recent years, plants have taken away substantial amount of nutrients from the soil because of the growing area of crops and the gradually increased yield (Feng, 2010). In addition, the amount of organic fertilizer applied in the field has generally declined (Mutegi et al., 2012), and trace elements could not be replenished in time. Thus, the available $\mathrm{Zn}$ in the soil gradually decreased with the passage of time. This phenomenon resulted in the prevalent deficiency of $\mathrm{Zn}$ in crops (Carroll and Loneragan, 1968; Alloway, 2009). Zn deficiency can cause dwarf plants, short internodes, suppression of leaf expansion and elongation, leaflets, twisted leaves, and wrinkled leaf margins. Albino corn seedlings and stiff Miller of rice seedlings are due to $\mathrm{Zn}$ 
deficiency (Rengel et al., 1998; Singh and Yashbir, 2017). At present, the application of $\mathrm{Zn}$ fertilizer to crops is the safest, most convenient, and effective approach to augment the micronutrient $\mathrm{Zn}$ deficiency in humans. This process can also effectively improve the symptoms of $\mathrm{Zn}$ deficiency in crops (Noulas et al., 2018). However, excessive application of $\mathrm{Zn}$ will inhibit the growth of crops, cause poisoning (Mateos-Naranjo et al., 2014), and can lead to toxicity, such as nutrient imbalances, growth inhibition, leaf chlorosis, and photosynthesis impairment (Todeschini et al., 2011; Cambrollé et al., 2012).

Photosynthesis is an important factor in plant growth and an indicator to assess plant growth status (Moss and Musgrabe, 1971; Silveira and Carvalho, 2016). Chlorophyll fluorescence is an effective tool to sense and assess the impact of $\mathrm{Zn}$ on the photosynthetic apparatus, and this tool has been used extensively to investigate the effects of various substances in crops (Appenroth et al., 2001; Prasad et al., 2001; Frankart et al., 2002; Drinovec et al., 2004). Zn plays a significant role in the regulation of the stomatal aperture, which accounts for the possible role of $\mathrm{Zn}$ in maintaining a high K content in the guard cells (Sharma et al., 1995). Cambrollé et al. (2013) showed that an appropriate $\mathrm{Zn}$ concentration $(60 \mathrm{mmol} / \mathrm{L})$ could increase the net photosynthetic rate $(\mathrm{Pn})$, but greater external $\mathrm{Zn}$ concentration $(90-130 \mathrm{mmol} / \mathrm{L})$ could negatively affect plant growth probably because of the recorded decline in the Pn. This process may be linked to the adverse effect of $\mathrm{Zn}$ on the photosynthetic electron transport.

Various grain industries have received increasing attention because of the improved human dietary structure (Ardiea et al., 2015). The millet (Setaria italica L.) originated from China and is an important strategic food crop in the country (Guo et al., 2018; Yuan et al., 2017). The millet is a traditional drought-resistant crop (Bai et al., 2009; Andersen and Nepal, 2017) and the preferred crop in drought-scarce areas in northern China. The main components of millet, including starch, protein, lipid, vitamins, and minerals, satisfy the various dietary needs of the human body (Usha et al., 1996). Low $\mathrm{Zn}$ availability affects crop yield and food production worldwide, and this phenomenon has led to the more efficient use of $\mathrm{Zn}$ in agriculture. The application of $\mathrm{Zn}$ fertilizer is an effective measure to increase nutrient $\mathrm{Zn}$ (Genty et al., 1989; Bouis and Welch, 2010; Gibson, 2006), but the safety of $\mathrm{Zn}$ to foxtail millet is ambiguous.

Studies on Zn fertilizers are mostly concentrated on rice (Jamalomidi et al., 2006), wheat (Khoshgoftarmanesh et al., 2006; Hacisalihoglu et al., 2003), and other crops (Gunes, 1996; Hu, 1991), but few reports have focused on millet production (Zong, 2011; Guo, 2014). In this experiment, millet was used to study the effects of different $\mathrm{Zn}$ concentrations on the growth of millet under different stages. Moreover, the optimal combination of conditions for the growth of millet was determined to provide a theoretical basis for the reasonable application of $\mathrm{Zn}$ fertilizer on millet.

\section{Materials and methods}

\section{Site and plant materials}

The pot experiments were conducted from May 2017 to October of 2017 at the cultivation base of the Resource and Environment College of Shanxi Agricultural University $\left(37^{\circ} 42^{\prime} \mathrm{N}, 112^{\circ} 55^{\prime} \mathrm{E}\right)$ in Shanxi, China. The area has a mean annual temperature of $9.9{ }^{\circ} \mathrm{C}$ and a frost-free period of 176 days. The precipitation is concentrated, and the mean annual rainfall is $462.9 \mathrm{~mm}$. The plant materials were 'Zhangzagu 10' (provided by the Zhangjiakou Academy of Agricultural Sciences of 
Hebei Province, China.) and 'Jingu 21' (provided by the Institute of Millet Research, Shanxi Academy of Agricultural Sciences, China). The soil used was calcareous soil, with $\mathrm{pH}$ value of 8.51 , organic matter content of $21.02 \mathrm{~g} / \mathrm{kg}$, alkali nitrogen content of $52.37 \mathrm{mg} / \mathrm{kg}$, available phosphorus content is $21.98 \mathrm{mg} / \mathrm{kg}$, available potassium content of $21.98 \mathrm{mg} / \mathrm{kg}$, total $\mathrm{N}$ content of $1.180 \mathrm{~g} / \mathrm{kg}$, total $\mathrm{P}$ content of $1.261 \mathrm{~g} / \mathrm{kg}$, and total $\mathrm{K}$ content of $20.18 \mathrm{~g} / \mathrm{kg}$. The seeds were sown on May 31, 2017. After 20 days of thinning out the seedlings, five seedlings were left in each pot.

\section{Treatment details and allocation}

The experiment was conducted in a completely random design. The seeds of 'Zhangzagu 10' and 'Jingu 21' were separately sown in pots with a diameter of $32 \mathrm{~cm}$ and a height of $26 \mathrm{~cm}$ under normal water content, and each pot was filled with $10 \mathrm{~kg}$ of soil, the cultivation temperature was $22-35^{\circ} \mathrm{C}$, relative humidity of atmosphere was 70 $80 \%$. The seeds were normally watered daily after germination to ensure the normal growth of the seedlings (by weighing method, the Moisture field was maintained at $13 \%-15 \%$ ). Different concentrations of $\mathrm{ZnSO}_{4} \cdot 7 \mathrm{H}_{2} \mathrm{O}$ solution were sprayed at the seedling stage (SL, $35 \mathrm{~d}$ after planting), booting stage (BT, 60 after planting), flowering stage (FE, $70 \mathrm{~d}$ after planting), and filling stage (FL, $90 \mathrm{~d}$ after planting). A control (no $\mathrm{Zn}$ application) was set simultaneously, and each treatment was repeated thrice. The $\mathrm{Zn}$ concentrations sprayed were $0,20,40,60,80$, and $100 \mathrm{mg} \cdot \mathrm{L}^{-1}$, and the corresponding samples were labeled as $\mathrm{CK}, \mathrm{Zn} 1, \mathrm{Zn} 2, \mathrm{Zn} 3, \mathrm{Zn} 4$, and $\mathrm{Zn} 5$. After 7 days of $\mathrm{Zn}$ treatment, the physiological and photosynthetic characteristics were measured.

\section{Determination of antioxidant enzyme activity}

Fresh plant leaves $(0.1 \mathrm{~g})$ were placed in an ice-cooled mortar, and $1 \mathrm{mg} \cdot \mathrm{L}^{-1}$ of $50 \mathrm{mM}$ phosphate buffer ( $\mathrm{pH} 7.8$ ) was added. The leaves were ground on ice, transferred to a $1.5 \mathrm{~mL}$ centrifuge tube, and centrifuged at $12000 \times \mathrm{g}$ for $15 \mathrm{~min}$ at $4{ }^{\circ} \mathrm{C}$. The supernatant was extracted to determine the superoxide dismutase (SOD), peroxidase (POD), and catalase (CAT) activities.

The SOD activity was determined using the nitroblue tetrazolium (NBT) photoreduction method (Gao, 2006). First, the NBT reaction solution was configured. The solution consisted of $50 \mathrm{mM}$ phosphate buffer $(\mathrm{pH} 7.8), 13 \mathrm{mM}$ L-methionine, $0.075 \mathrm{mM}$ NBT, $0.002 \mathrm{mM}$ riboflavin, and $0.01 \mathrm{mM}$ EDTA. Then, $5 \mathrm{~mL}$ of the reaction solution was added to the blank and control tubes. A portion of $50 \mu \mathrm{L}$ of the supernatant was taken from the test tube and mixed with $5 \mathrm{~mL}$ of the reaction solution. The control and test tubes were illuminated for $20 \mathrm{~min}$ under $4000 \mathrm{~lx}$ light conditions at $25^{\circ} \mathrm{C}$. The absorbance of the irradiated solution was measured at $560 \mathrm{~nm}$, and a non-irradiated complete reaction mixture served as a control. The result was calculated by inhibiting $50 \%$ of the NBT photochemical reduction as an enzyme unit. SOD activity was presented as the number of units per gram of fresh weight (U/g FW).

The POD activity was determined by the guaiacol method (Gao, 2006). The supernatant $(5 \mu \mathrm{L})$ was mixed with $3 \mathrm{~mL}$ of the reaction solution containing $3 \mathrm{~mL}$ of $0.1 \mathrm{mM}$ phosphate buffer (pH 6.0), $28 \mu \mathrm{L}$ of $30 \% \mathrm{H}_{2} \mathrm{O}_{2}$, and $19 \mu \mathrm{L}$ of guaiacol $(0.1 \%)$. The absorbance of the complete reaction mixture was measured at $470 \mathrm{~nm}$, and the $0.1 \mathrm{mM}$ phosphate buffer ( $\mathrm{pH}$ 6.0) served as a control. The change in absorbance every 3 min indicated the POD activity. 
The CAT activity was determined by the UV absorption method (Gao, 2006). The supernatant $(50 \mu \mathrm{L})$ was mixed with $3 \mathrm{~mL}$ of the reaction solution containing $2.7 \mathrm{~mL}$ of Tris- $\mathrm{HCl}$ buffer ( $\mathrm{pH} 7.0$ ) and $50 \mu \mathrm{L}$ of $200 \mathrm{mM} \mathrm{H}_{2} \mathrm{O}_{2}$. The absorbance of the complete reaction mixture was measured at $240 \mathrm{~nm}$. The decrease of 0.1 by A240 in 1 min was the enzymatic activity unit.

\section{Determination of lipid peroxidation}

The MDA content was determined by the thiobarbituric acid (TBA) spectrophotometry method (Zhao et al., 1994). Fresh plant leaves $(0.4 \mathrm{~g})$ were placed in an ice-cooled mortar, and $5 \mathrm{~mL}$ of $0.1 \%$ trichloroacetic acid was added. The leaves were ground on ice, and $5 \mathrm{~mL}$ of $0.5 \%$ TBA was added. The ground leaves were transferred to a $15 \mathrm{~mL}$ centrifuge tube. After boiling in water for $15 \mathrm{~min}$, the leaves were cooled to room temperature and centrifuged at $3000 \times g$ for $15 \mathrm{~min}$. The absorbance of the supernatant was measured at $560 \mathrm{~nm}$ and $600 \mathrm{~nm}$.

\section{Determination of photosynthetic pigment content}

The pigment contents of the leaves were determined using acetone extraction. Fresh plant leaves $(0.1 \mathrm{~g})$ were extracted in $10 \mathrm{~mL}$ of acetone $(80 \%, \mathrm{v} / \mathrm{v})$ and stored in the dark for $24 \mathrm{~h}$ (Gao, 2006). The absorbance of the supernatant was measured at 470, 646, and $663 \mathrm{~nm}$ (Eqs.1-3).

$$
\begin{gathered}
C \mathrm{a}=12.21 A 663-2.81 A 646 \\
C b=20.13 A 646-5.03 A 663 \\
C x . c=(1000 A 470-3.27 C a-104 C b) / 229
\end{gathered}
$$

\section{Determination of photosynthetic gas exchange parameters}

The $\mathrm{Pn}$, transpiration rate $(\mathrm{Tr})$, intercellular $\mathrm{CO}_{2}$ concentration $(\mathrm{Ci})$, and stomatal conductance (Gs) were measured using a CI-340 portable photosynthesis system (CID Bio-Science, Inc., USA, Fig. 1). The seedlings with uniform growth were randomly selected from each pot, and the photosynthetic gas exchange parameters were measured at 9:00-11:00 am on the 7th day after spraying the $\mathrm{ZnSO}_{4} \cdot 7 \mathrm{H}_{2} \mathrm{O}$ solution. Photosynthetically active radiation (PAR) at the leaf surface was approximately $1000 \pm 50 \mu \mathrm{mol} / \mathrm{m}^{2} / \mathrm{s}$. The temperature in the leaf chamber was $38 \pm 2{ }^{\circ} \mathrm{C}$, and ambient $\mathrm{CO}_{2}$ concentration was $420 \pm 30 \mu \mathrm{mol} / \mathrm{mol}$.

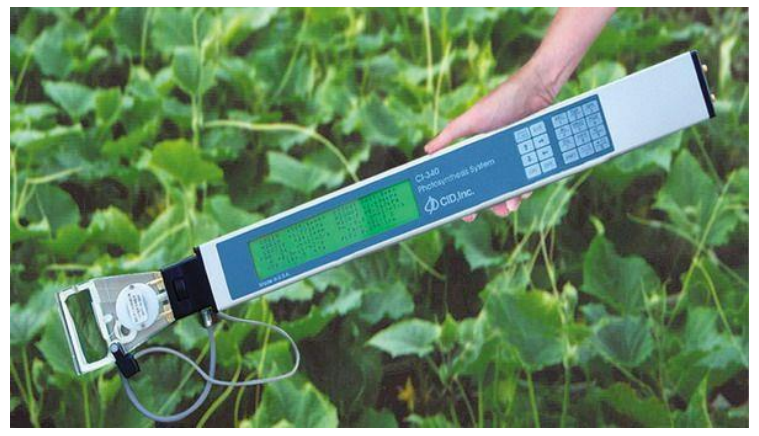

Figure 1. CI-340 portable photosynthesis system 


\section{Determination of chlorophyll fluorescence parameters}

Actual photochemical efficiency (ФPSII), photosynthetic electron transport rate (ETR), photochemical quenching coefficient (qP), non-photochemical quenching coefficient (qN), and maximum photochemical efficiency $(\mathrm{Fv} / \mathrm{Fm})$ were measured using a portable chlorophyll fluorometer PAM-2500 (Walz, Germany, Fig. 2). Prior to measurements, the leaves were first treated in the dark for $30 \mathrm{~min}$, and a beam of measurement light (less than $0.1 \mu \mathrm{mol}$ ) was irradiated on the fully dark-adapted leaves to obtain the initial fluorescence Fo. Then, saturated pulsed light $\left(8000 \mu \mathrm{mol} \mathrm{m}^{-2} \mathrm{~s}^{-1}\right)$ was turned on to obtain the maximum fluorescence Fm under dark adaptation (Marwood et al., 2001). Afterward, the endogenous actinic light $\left(600 \mu \mathrm{mol} \mathrm{m} \mathrm{m}^{-2} \mathrm{~s}^{-1}\right)$ was turned on. When the actual primary light energy capture efficiency ФPSII had stabilized, the action light was turned off, and the far-infrared light was illuminated (Schreiber et al., 1986, 2003). The ETR was automatically calculated by the instrument (Mayer et al., 2008). The different parameters were calculated as follows (Eqs.4-7):

$$
\begin{gathered}
F \mathrm{~V} / F m=(F m-F o) / F m \\
\Phi P S I I=\left(F m^{\prime}-F t\right) / F m^{\prime} \\
q P=\left(F m^{\prime}-F t\right) /\left(F m^{\prime}-F o^{\prime}\right) \\
q N=1-\left(F m^{\prime}-F o^{\prime}\right) /(F m-F o)
\end{gathered}
$$

\section{Statistical analysis}

The data were plotted using Microsoft Excel and analyzed by ANOVA using SPSS 17.0. Duncan's test $(\mathrm{P}<0.05)$ were used to determine the significance of differences between treatment means.

\section{Results}

\section{Effect of Zn on the antioxidant enzymatic activity of foxtail millet}

After $\mathrm{Zn}$ treatment, protective enzymes SOD, POD, and CAT in both cultivars increased first and then decreased with the increase in $\mathrm{Zn}$ concentration, and the level of change in these enzymes differed between the cultivars and among periods (Figs. 3-5). Among the three protective enzymes, $\mathrm{Zn}$ treatment of the same cultivars reached maximum effect in $\mathrm{Zn} 2$ and reached a significant level compared with the control $(\mathrm{P}<0.05)$. However, in 'Zhangzagu10', no significant difference in CAT was found between the control and Zn2 treatment during the SL stage (Fig. 3). However, the three enzymatic activities were lower in $\mathrm{Zn} 4$ than in CK, and the change was more obvious after Zn5 treatment. Figures 3-5 show that $\mathrm{Zn}$ treatment of the two millet varieties was most obvious at the BT stage.

Compared with CK, during the BT stage, after 7 days of $\mathrm{Zn} 2$ treatment, the SOD, POD, and CAT activities of 'Jingu 21 ' increased by $28.2 \%, 61.1 \%$, and $35.1 \%$, respectively. By contrast, the corresponding values of 'Zhangzagu 10' increased by $11.3 \%, 15.5 \%$, and $10.6 \%$. After 7 days of Zn5 treatment, compared with CK, the SOD, POD, and CAT activities of 'Jingu 21 ' decreased by $17.2 \%, 20.4 \%$, and $16.8 \%$ ' respectively, while those of 'Zhangzagu 10' were reduced by $11.7 \%, 12.1 \%$, and 12.6\%' respectively (Figs. 3-5). 


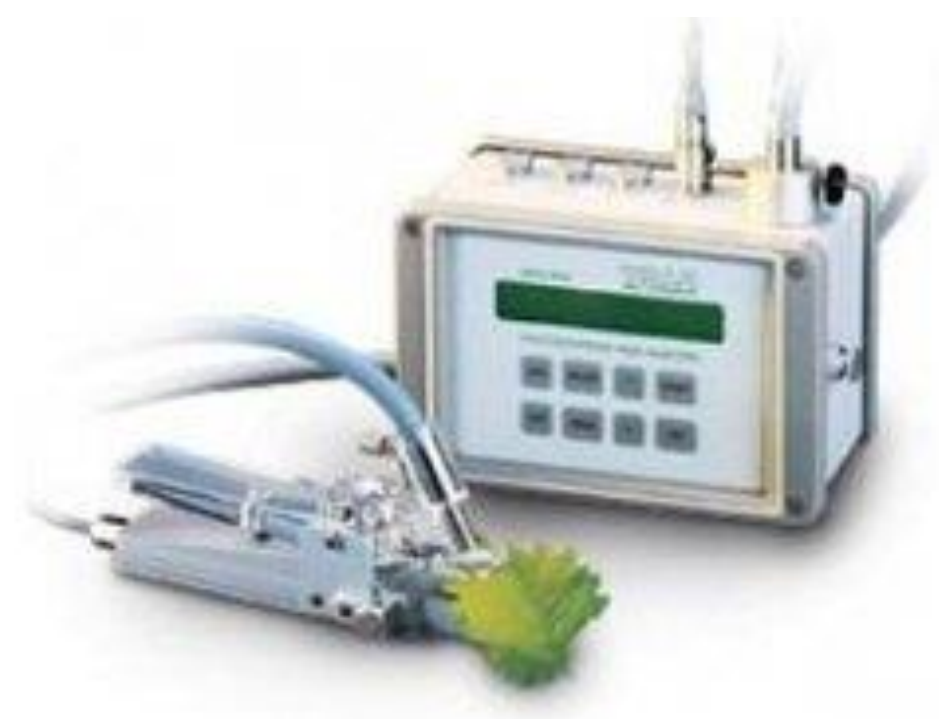

Figure 2. Portable chlorophyll fluorometer PAM-2500

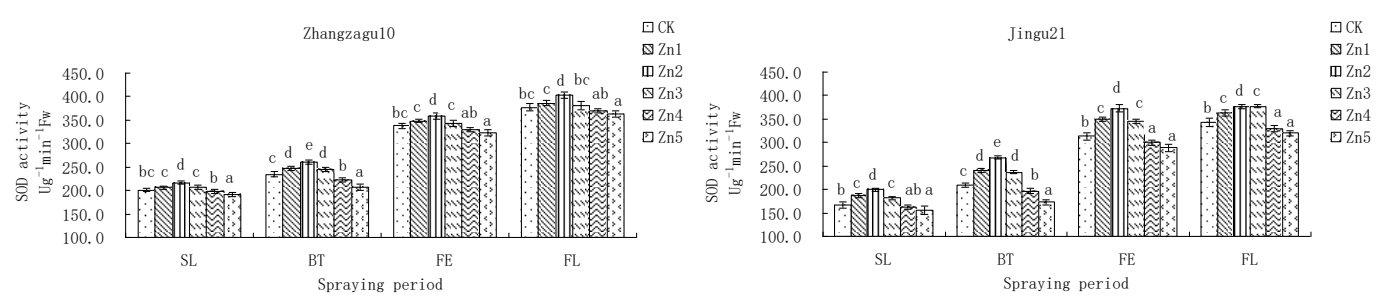

Figure 3. Effects of Zn on the superoxide dismutase (SOD) activity in the leaves of 'Zhangzagu 10 ' and 'Jingu 21' at the different growth stages
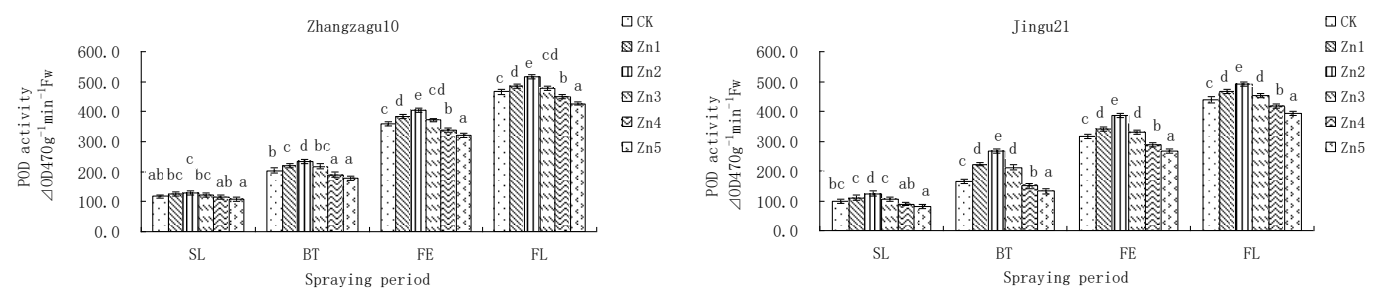

Figure 4. Effects of Zn on peroxidase (POD) activity in the leaves of 'Zhangzagu 10' and 'Jingu 21 'in the different growth stages
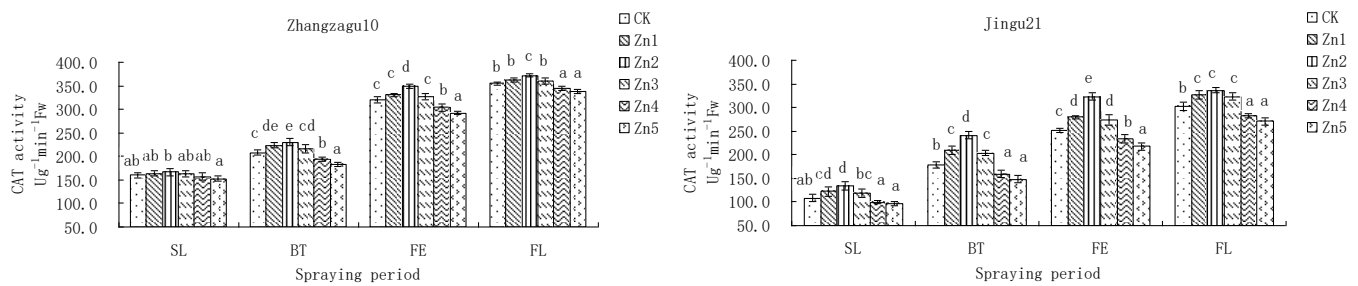

Figure 5. Effects of Zn on the catalase (CAT) activity in the leaves of 'Zhangzagu 10' and 'Jingu 21' at the different growth stages 


\section{Effect of Zn on the MDA content of foxtail millet}

The trend of MDA was opposite to that of the protective enzyme activity. The MDA decreased first and then increased with the increase in $\mathrm{Zn}$ concentration. MDA content reached minimum in $\mathrm{Zn} 2$ and then gradually increased until $\mathrm{Zn} 4$ treatment, during which the MDA content was higher than that in CK. Figure 4 shows that the MDA content had the greatest impact during the BT stage.

Compared with CK, after 7 days of Zn2 treatment, the MDA activities of 'Jingu 21' in SL, BT, FE, and FL were decreased by $26.0 \%, 35.9 \%, 15.4 \%$ and $13.3 \%$, respectively, while those of 'Zhangzagu 10' were reduced by $14.2 \%, 16.7 \%, 11.7 \%$ and $10.7 \%$, respectively (Fig. 6).
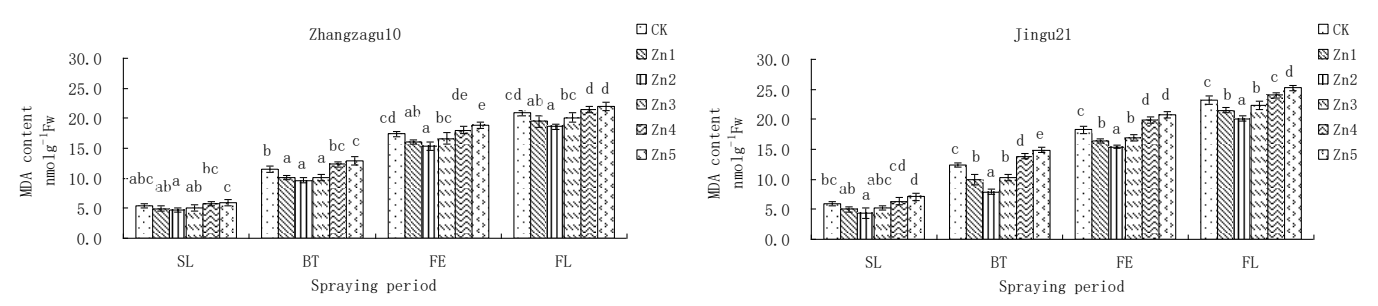

Figure 6. Effects of Zn on the malondialdehyde (MDA) content in the leaves of 'Zhangzagu 10' and 'Jingu 21' at the different growth stages

\section{Effect of Zn on the pigments of foxtail millet}

The average amounts of pigments in the leaves as affected by spraying period and spraying concentrations are presented in Tables 1 and 2. The pigment contents in the leaves of foxtail millet increased with increasing $\mathrm{Zn}$ concentrations until $\mathrm{Zn} 2$. However, the pigment contents declined at $\mathrm{Zn} 4$ and $\mathrm{Zn} 5$ treatments, and the levels were even lower than those of the CK. Although both cultivars showed similar trends in the different stages, the degrees of increase or decrease of chlorophyll contents in the cultivars were not identical. Chlorophyll a, chlorophyll b, chlorophyll, and carotenoid were most affected by Zn treatment during the BT stage.

Compared with CK, during the BT stage, after 7 days of $\mathrm{Zn} 2$ treatment, the chlorophyll a, chlorophyll b, chlorophyll, and carotenoid of 'Jingu 21' increased by $27.1 \%, 36.7 \%, 28.9 \%$, and $9.7 \%$, respectively, while those of 'Zhangzagu 10 ' increased by $13.3 \%, 27.8 \%, 15.9 \%$, and $8.0 \%$, respectively.

In addition to the carotenoid during SL of 'Jingu 21', these pigments reached significant levels. After 7 days of Zn5 treatment, compared with CK, chlorophyll a, chlorophyll b, chlorophyll, and carotenoid of 'Jingu 21' decreased by $11.6 \%, 31.3 \%$, $15.3 \%$, and $7.7 \%$, respectively, while those of 'Zhangzagu 10 ' declined by $6.5 \%$, $23.5 \%, 9.6 \%$, and $6.5 \%$, respectively. These values almost reached significant levels (Tables 1 and 2).

\section{Effect of Zn on the photosynthetic gas exchange parameters of foxtail millet}

After $\mathrm{Zn}$ treatment, the Pn, Gs, and $\mathrm{Tr}$ in both cultivars increased first and then decreased with the increase of $\mathrm{Zn}$ concentration. The change in these indices differed between cultivars and among periods (Figs. 7-9). 
Among these three indices, $\mathrm{Zn}$ treatment reached maximum effect in $\mathrm{Zn} 2$ and then gradually decreased. From the Zn4 treatment, these indices were lower than $\mathrm{CK}$ and reached a significant level between treatments. Figures 7-9 show that the $\mathrm{Zn}$ treatment of the two millet varieties was most obvious during BT.

Table 1. Effects of $\mathrm{Zn}$ on the pigment contents in the leaves of 'Zhangzagu 10' at the different growth stages

\begin{tabular}{|c|c|c|c|c|c|c|}
\hline Cultivar & Period & Treatment & $\begin{array}{c}\text { Chlorophyll a } \\
(\mathrm{mg} / \mathrm{gFw})\end{array}$ & $\begin{array}{c}\text { Chlorophyll b } \\
(\mathrm{mg} / \mathrm{gFw})\end{array}$ & $\begin{array}{c}\text { Chlorophyll } \\
\text { (mg/gFw) }\end{array}$ & $\begin{array}{c}\text { Carotenoid } \\
(\mathrm{mg} / \mathrm{gFw})\end{array}$ \\
\hline \multirow{24}{*}{ 'Zhangza 10' } & \multirow{6}{*}{ SL } & CK & $9.66 \pm 0.18 c$ & $3.77 \pm 0.17 b$ & $13.43 \pm 0.11 \mathrm{c}$ & $1.40 \pm 0.04 \mathrm{ab}$ \\
\hline & & $\mathrm{Zn} 1$ & $10.13 \pm 0.05 \mathrm{~d}$ & $4.07 \pm 0.12 \mathrm{~cd}$ & $14.21 \pm 0.17 \mathrm{e}$ & $1.47 \pm 0.04 \mathrm{c}$ \\
\hline & & $\mathrm{Zn} 2$ & $10.40 \pm 0.09 \mathrm{e}$ & $4.21 \pm 0.03 \mathrm{~d}$ & $14.62 \pm 0.10 \mathrm{f}$ & $1.47 \pm 0.03 \mathrm{c}$ \\
\hline & & $\mathrm{Zn} 3$ & $9.99 \pm 0.07 \mathrm{~d}$ & $3.97 \pm 0.11 \mathrm{c}$ & $13.96 \pm 0.04 \mathrm{~d}$ & $1.42 \pm 0.01 b c$ \\
\hline & & $\mathrm{Zn} 4$ & $9.35 \pm 0.10 b$ & $3.47 \pm 0.09 \mathrm{a}$ & $12.82 \pm 0.19 b$ & $1.36 \pm 0.05 \mathrm{ab}$ \\
\hline & & $\mathrm{Zn} 5$ & $9.14 \pm 0.10 \mathrm{a}$ & $3.27 \pm 0.11 \mathrm{a}$ & $12.41 \pm 0.10 \mathrm{a}$ & $1.35 \pm 0.02 \mathrm{a}$ \\
\hline & \multirow{6}{*}{ BT } & CK & $16.39 \pm 0.09 c$ & $3.59 \pm 0.12 \mathrm{c}$ & $19.99 \pm 0.20 c$ & $4.19 \pm 0.09 c$ \\
\hline & & $\mathrm{Zn} 1$ & $17.48 \pm 0.12 \mathrm{~d}$ & $3.99 \pm 0.15 \mathrm{~d}$ & $21.47 \pm 0.08 \mathrm{~d}$ & $4.42 \pm 0.07 \mathrm{de}$ \\
\hline & & $\mathrm{Zn} 2$ & $18.57 \pm 0.06 \mathrm{e}$ & $4.59 \pm 0.08 \mathrm{e}$ & $23.17 \pm 0.12 \mathrm{e}$ & $4.53 \pm 0.06 \mathrm{e}$ \\
\hline & & $\mathrm{Zn} 3$ & $17.28 \pm 0.17 \mathrm{~d}$ & $3.96 \pm 0.16 \mathrm{~d}$ & $21.24 \pm 0.12 \mathrm{~d}$ & $4.33 \pm 0.09 \mathrm{~d}$ \\
\hline & & $\mathrm{Zn} 4$ & $15.60 \pm 0.13 b$ & $3.20 \pm 0.13 b$ & $18.81 \pm 0.14 \mathrm{~b}$ & $4.05 \pm 0.06 \mathrm{~b}$ \\
\hline & & Zn5 & $15.33 \pm 0.11 \mathrm{a}$ & $2.75 \pm 0.13 \mathrm{a}$ & $18.08 \pm 0.12 \mathrm{a}$ & $3.92 \pm 0.04 \mathrm{a}$ \\
\hline & \multirow{6}{*}{$\mathrm{FE}$} & CK & $16.46 \pm 0.11 \mathrm{c}$ & $3.71 \pm 0.10 b c$ & $20.16 \pm 0.16 c$ & $4.79 \pm 0.05 c$ \\
\hline & & $\mathrm{Zn} 1$ & $17.14 \pm 0.06 \mathrm{e}$ & $3.92 \pm 0.13 c$ & $21.06 \pm 0.11 \mathrm{~d}$ & $4.97 \pm 0.08 \mathrm{de}$ \\
\hline & & $\mathrm{Zn} 2$ & $17.48 \pm 0.09 \mathrm{f}$ & $4.43 \pm 0.07 \mathrm{~d}$ & $21.92 \pm 0.16 \mathrm{e}$ & $5.04 \pm 0.06 \mathrm{e}$ \\
\hline & & $\mathrm{Zn} 3$ & $16.97 \pm 0.07 \mathrm{~d}$ & $3.85 \pm 0.12 c$ & $20.82 \pm 0.09 d$ & $4.91 \pm 0.06 \mathrm{~d}$ \\
\hline & & $\mathrm{Zn} 4$ & $16.03 \pm 0.11 b$ & $3.51 \pm 0.15 \mathrm{ab}$ & $19.54 \pm 0.16 b$ & $4.65 \pm 0.10 \mathrm{~b}$ \\
\hline & & $\mathrm{Zn} 5$ & $15.76 \pm 0.03 \mathrm{a}$ & $3.36 \pm 0.19 \mathrm{a}$ & $19.11 \pm 0.17 \mathrm{a}$ & $4.52 \pm 0.04 a$ \\
\hline & \multirow{6}{*}{ FL } & CK & $16.10 \pm 0.07 \mathrm{c}$ & $3.38 \pm 0.03 b$ & $19.49 \pm 0.10 \mathrm{c}$ & $4.06 \pm 0.04 \mathrm{~b}$ \\
\hline & & $\mathrm{Zn} 1$ & $16.42 \pm 0.06 \mathrm{de}$ & $3.54 \pm 0.07 b c$ & $19.97 \pm 0.10 \mathrm{e}$ & $4.14 \pm 0.06 b c$ \\
\hline & & $\mathrm{Zn} 2$ & $16.56 \pm 0.17 \mathrm{e}$ & $3.75 \pm 0.12 \mathrm{c}$ & $20.31 \pm 0.10 \mathrm{f}$ & $4.23 \pm 0.07 \mathrm{c}$ \\
\hline & & $\mathrm{Zn} 3$ & $16.32 \pm 0.06 \mathrm{~d}$ & $3.43 \pm 0.09 b$ & $19.75 \pm 0.15 \mathrm{~d}$ & $4.12 \pm 0.03 b c$ \\
\hline & & $\mathrm{Zn} 4$ & $15.85 \pm 0.03 b$ & $3.30 \pm 0.12 \mathrm{ab}$ & $19.15 \pm 0.14 b$ & $4.02 \pm 0.01 \mathrm{ab}$ \\
\hline & & Zn5 & $15.59 \pm 0.12 \mathrm{a}$ & $3.13 \pm 0.23 \mathrm{a}$ & $18.71 \pm 0.11 \mathrm{a}$ & $3.93 \pm 0.11 \mathrm{a}$ \\
\hline
\end{tabular}

Values are mean $\pm \mathrm{SE}(\mathrm{n}=3)$. Different letters in the same column indicate significant difference at the $\mathrm{P}<0.05$ level by Duncan's new multiple range test. SL, BT, FE, and FL represent the seedling, booting, flowering, and filling stages, respectively
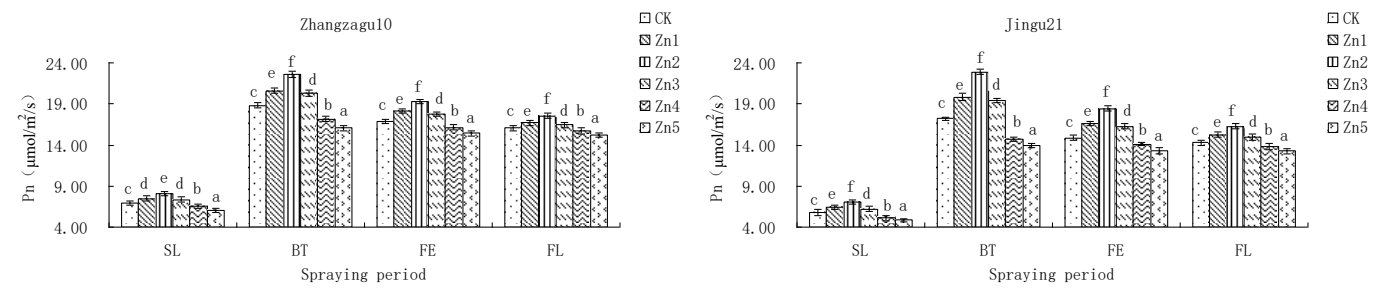

Figure 7. Effects of Zn on the net photosynthesis rate (Pn) in the leaves of 'Zhangzagu 10' and 'Jingu 21 ' at the different growth stages 

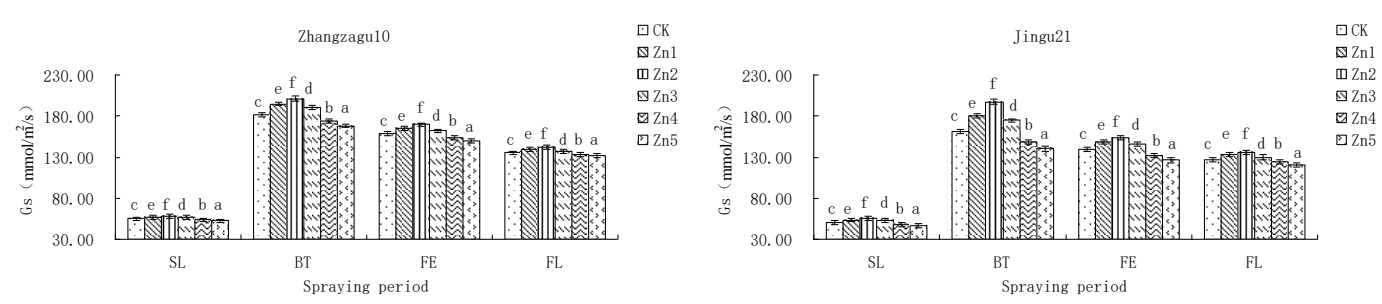

Figure 8. Effects of Zn on stomatal conductance (Gs) in the leaves of 'Zhangzagu 10' and 'Jingu 21' at the different growth stages
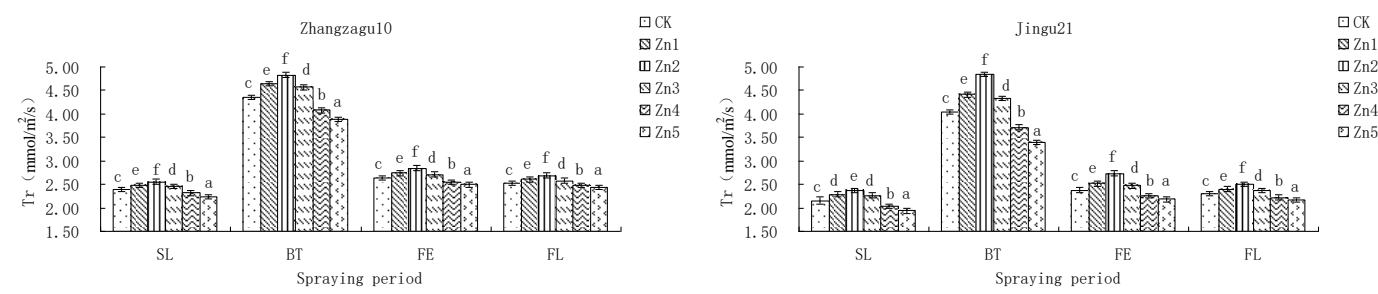

Figure 9. Effects of Zn on transpiration rate (Tr) in the leaves of 'Zhangzagu 10' and 'Jingu 21 ' at the different growth stages

During the BT stage, compared with $\mathrm{CK}$, after 7 days of $\mathrm{Zn} 2$ treatment, the Pn, Gs, and $\operatorname{Tr}$ of 'Jingu 21 ' increased by $33.1 \%, 22.4 \%$, and $20.0 \%$, respectively, while those of 'Zhangzagu 10' increased by $19.9 \%, 10.5 \%$, and $10.7 \%$, respectively. After 7 days of Zn5 treatment, compared with $\mathrm{CK}$, the Pn, Gs, and $\mathrm{Tr}$ of 'Jingu 21' decreased by $19.1 \%, 13.1 \%$, and $16.0 \%$, respectively, while those of 'Zhangzagu 10 ' declined by $14.6 \%, 7.7 \%$, and $11.1 \%$, respectively (Figs. 7-9).

As the $\mathrm{Zn}$ concentration increased, $\mathrm{Ci}$ decreased first and then increased, which was opposite to the trend of Pn. Among the different $\mathrm{Zn}$ treatments for the same period, the reduction of $\mathrm{Zn} 2$ treatment was the most obvious. Figure 8 shows that, after $\mathrm{Zn}$ treatment, $\mathrm{Ci}$ had the greatest impact during the BT stage.

Compared with the control, after 7 days of $\mathrm{Zn} 2$ treatment, the $\mathrm{Ci}$ of 'Jingu 21' during SL, BT, FE, and FL decreased by $16.9 \%, 23.7 \%, 18.3 \%$, and $13.8 \%$ respectively, while those of 'Zhangzagu 10' declined by $11.2 \%, 16.4 \%, 13.7 \%$, and $9.5 \%$, respectively (Fig. 10). During BT, the $\mathrm{Ci}$ of Jingu 21 was as follows: $\mathrm{Zn} 5>\mathrm{Zn} 4>\mathrm{CK}>\mathrm{Zn} 3>\mathrm{Zn} 2>\mathrm{Zn} 1$. 'Zhangzagu 10' had the same trend. Although 'Zhangzagu 10' and 'Jingu 21' showed similar trends in the different concentrations, the degrees of increase or decrease in $\mathrm{Ci}$ for the cultivars were not same.
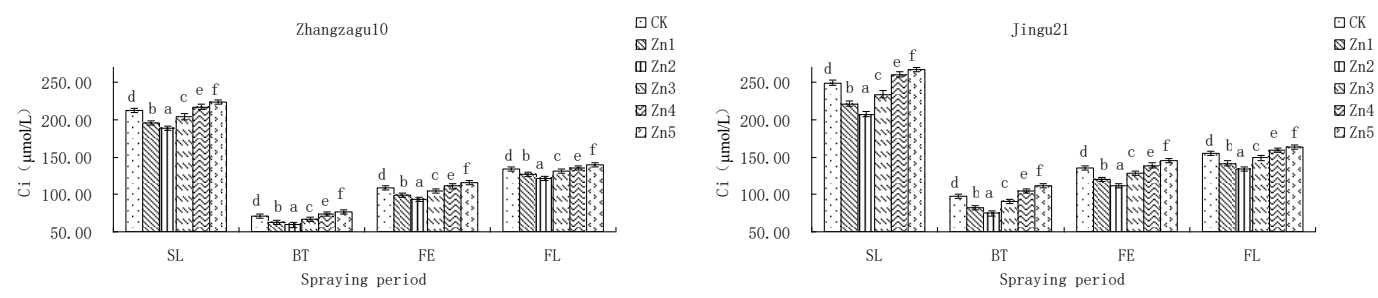

Figure 10. Effects of Zn on intercellular $\mathrm{CO}_{2}$ concentration (Ci) in the leaves of 'Zhangzagu 10' and 'Jingu 21 ' at the different growth stages 
Table 2. Effects of Zn on the pigment contents in the leaves of 'Jingu 21' at the different growth stages

\begin{tabular}{|c|c|c|c|c|c|c|}
\hline Cultivar & Period & Treatment & $\begin{array}{c}\text { Chlorophyll a } \\
(\mathrm{mg} / \mathrm{gFw})\end{array}$ & $\begin{array}{c}\text { Chlorophyll b } \\
(\mathrm{mg} / \mathrm{gFw})\end{array}$ & $\begin{array}{c}\text { Chlorophyll } \\
(\mathrm{mg} / \mathrm{gFw})\end{array}$ & $\begin{array}{c}\text { Carotenoid } \\
(\mathbf{m g} / \mathbf{g F w})\end{array}$ \\
\hline \multirow{24}{*}{ 'Jingu 21' } & \multirow{6}{*}{ SL } & $\mathrm{CK}$ & $7.36 \pm 0.11 c$ & $2.38 \pm 0.16 b c$ & $9.74 \pm 0.16 c$ & $1.31 \pm 0.09 \mathrm{ab}$ \\
\hline & & $\mathrm{Zn} 1$ & $8.02 \pm 0.12 \mathrm{~d}$ & $2.60 \pm 0.32 c$ & $10.62 \pm 0.25 \mathrm{~d}$ & $1.38 \pm 0.13 \mathrm{ab}$ \\
\hline & & $\mathrm{Zn} 2$ & $8.36 \pm 0.09 \mathrm{e}$ & $2.95 \pm 0.13 d$ & $11.32 \pm 0.12 \mathrm{e}$ & $1.42 \pm 0.03 b$ \\
\hline & & $\mathrm{Zn} 3$ & $7.86 \pm 0.05 \mathrm{~d}$ & $2.56 \pm 0.14 c$ & $10.41 \pm 0.19 \mathrm{~d}$ & $1.34 \pm 0.05 \mathrm{ab}$ \\
\hline & & $\mathrm{Zn} 4$ & $7.02 \pm 0.09 b$ & $2.17 \pm 0.07 \mathrm{ab}$ & $9.19 \pm 0.16 b$ & $1.27 \pm 0.01 \mathrm{a}$ \\
\hline & & Zn5 & $6.66 \pm 0.09 \mathrm{a}$ & $1.95 \pm 0.17 \mathrm{a}$ & $8.61 \pm 0.09 \mathrm{a}$ & $1.26 \pm 0.08 \mathrm{a}$ \\
\hline & \multirow{6}{*}{ BT } & $\mathrm{CK}$ & $15.51 \pm 0.07 \mathrm{c}$ & $3.57 \pm 0.14 \mathrm{c}$ & $19.08 \pm 0.12 c$ & $3.84 \pm 0.03 c$ \\
\hline & & $\mathrm{Zn} 1$ & $17.28 \pm 0.04 \mathrm{e}$ & $4.03 \pm 0.07 \mathrm{~d}$ & $21.30 \pm 0.11 \mathrm{e}$ & $4.08 \pm 0.05 \mathrm{~d}$ \\
\hline & & $\mathrm{Zn} 2$ & $19.71 \pm 0.12 \mathrm{f}$ & $4.88 \pm 0.03 \mathrm{e}$ & $24.60 \pm 0.14 \mathrm{f}$ & $4.22 \pm 0.03 \mathrm{e}$ \\
\hline & & $\mathrm{Zn} 3$ & $16.98 \pm 0.07 \mathrm{~d}$ & $3.95 \pm 0.10 \mathrm{~d}$ & $20.93 \pm 0.10 d$ & $4.01 \pm 0.09 \mathrm{~d}$ \\
\hline & & $\mathrm{Zn} 4$ & $14.14 \pm 0.07 b$ & $2.96 \pm 0.10 b$ & $17.10 \pm 0.08 \mathrm{~b}$ & $3.68 \pm 0.08 b$ \\
\hline & & Zn5 & $13.71 \pm 0.03 \mathrm{a}$ & $2.45 \pm 0.05 \mathrm{a}$ & $16.16 \pm 0.02 \mathrm{a}$ & $3.55 \pm 0.01 \mathrm{a}$ \\
\hline & \multirow{6}{*}{ FE } & $\mathrm{CK}$ & $16.18 \pm 0.05 c$ & $2.25 \pm 0.07 b c$ & $18.43 \pm 0.12 c$ & $4.27 \pm 0.07 b c$ \\
\hline & & $\mathrm{Zn} 1$ & $17.56 \pm 0.16 \mathrm{e}$ & $2.49 \pm 0.16 c$ & $20.05 \pm 0.27 \mathrm{e}$ & $4.47 \pm 0.09 \mathrm{de}$ \\
\hline & & $\mathrm{Zn} 2$ & $18.18 \pm 0.14 \mathrm{f}$ & $2.83 \pm 0.18 \mathrm{~d}$ & $21.00 \pm 0.09 f$ & $4.58 \pm 0.10 \mathrm{e}$ \\
\hline & & $\mathrm{Zn} 3$ & $17.06 \pm 0.10 \mathrm{~d}$ & $2.39 \pm 0.23 c$ & $19.46 \pm 0.20 \mathrm{~d}$ & $4.41 \pm 0.10 \mathrm{~cd}$ \\
\hline & & $\mathrm{Zn} 4$ & $15.41 \pm 0.05 b$ & $2.10 \pm 0.13 c$ & $17.51 \pm 0.17 b$ & $4.12 \pm 0.08 \mathrm{ab}$ \\
\hline & & Zn5 & $14.82 \pm 0.07 \mathrm{a}$ & $1.95 \pm 0.07 \mathrm{a}$ & $16.77 \pm 0.13 \mathrm{a}$ & $3.99 \pm 0.06 \mathrm{a}$ \\
\hline & \multirow{6}{*}{ FL } & $\mathrm{CK}$ & $15.91 \pm 0.08 \mathrm{c}$ & $2.11 \pm 0.23 \mathrm{abc}$ & $18.01 \pm 0.15 \mathrm{c}$ & $3.55 \pm 0.07 \mathrm{bc}$ \\
\hline & & $\mathrm{Zn} 1$ & $16.44 \pm 0.16 \mathrm{~d}$ & $2.27 \pm 0.28 b c$ & $18.71 \pm 0.17 \mathrm{~d}$ & $3.66 \pm 0.08 \mathrm{~cd}$ \\
\hline & & $\mathrm{Zn} 2$ & $16.91 \pm 0.05 \mathrm{e}$ & $2.41 \pm 0.23 c$ & $19.32 \pm 0.22 \mathrm{e}$ & $3.77 \pm 0.10 \mathrm{~d}$ \\
\hline & & $\mathrm{Zn} 3$ & $16.28 \pm 0.05 \mathrm{~d}$ & $2.19 \pm 0.17 \mathrm{abc}$ & $18.47 \pm 0.18 \mathrm{~d}$ & $3.62 \pm 0.06 c$ \\
\hline & & $\mathrm{Zn} 4$ & $15.39 \pm 0.12 b$ & $2.04 \pm 0.08 \mathrm{ab}$ & $17.43 \pm 0.19 b$ & $3.46 \pm 0.05 \mathrm{ab}$ \\
\hline & & Zn5 & $14.87 \pm 0.13 \mathrm{a}$ & $1.86 \pm 0.05 \mathrm{a}$ & $16.73 \pm 0.16 \mathrm{a}$ & $3.37 \pm 0.01 \mathrm{a}$ \\
\hline
\end{tabular}

Values are mean $\pm \operatorname{SE}(n=3)$. Different letters in the same column indicate significant difference at the $\mathrm{P}<0.05$ level by Duncan's new multiple range test. SL, BT, FE, and FL represent the seedling, booting, flowering, and filling stages, respectively

\section{Effect of Zn on the chlorophyll fluorescence parameters of foxtail millet}

Tables 3 and 4 show that the chlorophyll fluorescence parameters of foxtail millet increased with increasing $\mathrm{Zn}$ concentrations until $\mathrm{Zn} 2$. Then, at the $\mathrm{Zn} 4$ and $\mathrm{Zn} 5$ treatments, the chlorophyll fluorescence parameters declined, even lower than those at $\mathrm{CK}$, except the values of $\mathrm{qN}$. These indicators showed the greatest impact on millet during BT and had greater effect on 'Jingu 21' than 'Zhangzagu 10'.

During BT, compared with CK, after 7 days of $\mathrm{Zn} 2$ treatment, the Fo, Fm, Fv/Fm, and $\mathrm{Fv} / \mathrm{Fo}$ of 'Jingu 21' increased by $5.5 \%, 42.5 \%, 11.4 \%$, and $50.4 \%$, respectively, while those of 'Zhangzagu 10' increased by $4.9 \%, 27.6 \%, 7.6 \%$, and $30.9 \%$, respectively. After 7 days of Zn5 treatment, compared with CK, the Fo, Fm, Fv/Fm, and Fv/Fo of 'Jingu 21' decreased by $6.7 \%, 18.5 \%, 6.4 \%$, and $18.3 \%$, respectively, while those of 'Zhangzagu 10' declined by $5.2 \%, 13.9 \%, 4.3 \%$ and $13.1 \%$, respectively (Tables 3 and 4). 
Table 3. Effects of Zn on chlorophyll fluorescence parameters of 'Zhangzagu 10' in the different growth stages

\begin{tabular}{|c|c|c|c|c|c|c|c|c|c|c|}
\hline Cultivar & Period & \begin{tabular}{|l|} 
Treatment \\
\end{tabular} & Fo & $\mathbf{F m}$ & Fv/Fm & Fv/Fo & Y2 & ETR & $\mathbf{q P}$ & $q \mathbf{N}$ \\
\hline \multirow{24}{*}{ 'Zhangza 10' } & \multirow{6}{*}{ SL } & CK & $0.226 c$ & $0.866 \mathrm{c}$ & $0.738 \mathrm{c}$ & $2.824 \mathrm{c}$ & $0.214 b c$ & $69.3 \mathrm{c}$ & $0.431 \mathrm{c}$ & $1.144 \mathrm{c}$ \\
\hline & & $\mathrm{Zn} 1$ & $0.231 \mathrm{~d}$ & $0.935 \mathrm{e}$ & $0.753 \mathrm{e}$ & $3.041 \mathrm{e}$ & $0.227 \mathrm{de}$ & $71.8 \mathrm{e}$ & $0.450 \mathrm{~d}$ & $1.063 \mathrm{~b}$ \\
\hline & & $\mathrm{Zn} 2$ & $0.235 \mathrm{e}$ & $0.978 \mathrm{f}$ & $0.760 f$ & $3.159 \mathrm{f}$ & $0.233 \mathrm{e}$ & $74.5 \mathrm{f}$ & $0.466 \mathrm{e}$ & $0.982 \mathrm{a}$ \\
\hline & & $\mathrm{Zn} 3$ & $0.231 \mathrm{~d}$ & $0.913 \mathrm{~d}$ & $0.747 d$ & $2.958 \mathrm{~d}$ & $0.219 \mathrm{~cd}$ & $70.8 \mathrm{~d}$ & $0.443 d$ & $1.068 \mathrm{~b}$ \\
\hline & & $\mathrm{Zn} 4$ & $0.222 b$ & $0.808 \mathrm{~b}$ & $0.726 \mathrm{~b}$ & $2.647 \mathrm{~b}$ & $0.206 \mathrm{~b}$ & $67.5 \mathrm{~b}$ & $0.409 \mathrm{~b}$ & $1.197 \mathrm{~d}$ \\
\hline & & $\mathrm{Zn} 5$ & $0.217 \mathrm{a}$ & $0.767 \mathrm{a}$ & $0.717 \mathrm{a}$ & $2.537 \mathrm{a}$ & $0.196 \mathrm{a}$ & $65.6 \mathrm{a}$ & $0.386 \mathrm{a}$ & $1.295 \mathrm{e}$ \\
\hline & \multirow{6}{*}{ BT } & CK & $0.240 \mathrm{c}$ & $0.803 c$ & $0.701 \mathrm{c}$ & $2.341 \mathrm{c}$ & $0.231 \mathrm{c}$ & $68.2 \mathrm{c}$ & $0.451 \mathrm{c}$ & $1.049 \mathrm{~d}$ \\
\hline & & Zn1 & $0.248 \mathrm{~d}$ & $0.916 \mathrm{e}$ & $0.729 d$ & $2.697 \mathrm{~d}$ & $0.250 \mathrm{~d}$ & $72.1 \mathrm{e}$ & $0.489 \mathrm{e}$ & $0.881 \mathrm{~b}$ \\
\hline & & $\mathrm{Zn} 2$ & $0.252 \mathrm{e}$ & $1.024 \mathrm{f}$ & $0.754 \mathrm{e}$ & $3.063 \mathrm{e}$ & $0.266 \mathrm{e}$ & $74.9 \mathrm{f}$ & $0.521 \mathrm{f}$ & $0.751 \mathrm{a}$ \\
\hline & & $\mathrm{Zn} 3$ & $0.246 \mathrm{~d}$ & $0.895 \mathrm{~d}$ & $0.726 \mathrm{~d}$ & $2.646 \mathrm{~d}$ & $0.244 \mathrm{~d}$ & $71.1 \mathrm{~d}$ & $0.478 d$ & $0.911 \mathrm{c}$ \\
\hline & & $\mathrm{Zn} 4$ & $0.233 b$ & $0.738 b$ & $0.684 b$ & $2.169 \mathrm{~b}$ & $0.211 \mathrm{~b}$ & $64.7 \mathrm{~b}$ & $0.413 b$ & $1.152 \mathrm{e}$ \\
\hline & & $\mathrm{Zn} 5$ & $0.228 \mathrm{a}$ & $0.691 \mathrm{a}$ & $0.670 \mathrm{a}$ & $2.035 \mathrm{a}$ & $0.201 \mathrm{a}$ & $62.7 \mathrm{a}$ & $0.383 a$ & $1.237 \mathrm{f}$ \\
\hline & \multirow{6}{*}{ FE } & $\mathrm{CK}$ & $0.236 \mathrm{c}$ & $0.842 \mathrm{c}$ & $0.719 \mathrm{c}$ & $2.562 \mathrm{c}$ & $0.219 \mathrm{c}$ & $71.1 \mathrm{c}$ & $0.441 \mathrm{c}$ & $0.932 \mathrm{~d}$ \\
\hline & & $\mathrm{Zn} 1$ & $0.242 \mathrm{~d}$ & $0.941 \mathrm{e}$ & $0.743 \mathrm{e}$ & $2.896 \mathrm{e}$ & $0.234 \mathrm{e}$ & $74.3 \mathrm{e}$ & $0.464 d$ & $0.842 b$ \\
\hline & & $\mathrm{Zn} 2$ & $0.246 \mathrm{e}$ & $1.042 \mathrm{f}$ & $0.764 f$ & $3.236 \mathrm{f}$ & $0.244 \mathrm{f}$ & $77.0 \mathrm{f}$ & $0.497 \mathrm{e}$ & $0.777 \mathrm{a}$ \\
\hline & & $\mathrm{Zn} 3$ & $0.240 \mathrm{~d}$ & $0.911 \mathrm{~d}$ & $0.736 \mathrm{~d}$ & $2.795 d$ & $0.227 \mathrm{~d}$ & $73.3 \mathrm{~d}$ & $0.460 \mathrm{~d}$ & $0.874 \mathrm{c}$ \\
\hline & & $\mathrm{Zn} 4$ & $0.231 \mathrm{~b}$ & $0.785 b$ & $0.705 b$ & $2.394 \mathrm{~b}$ & $0.205 b$ & $68.3 b$ & $0.412 b$ & $0.995 \mathrm{e}$ \\
\hline & & $\mathrm{Zn} 5$ & $0.226 \mathrm{a}$ & $0.749 \mathrm{a}$ & $0.698 \mathrm{a}$ & $2.307 \mathrm{a}$ & $0.195 \mathrm{a}$ & $66.5 \mathrm{a}$ & $0.398 \mathrm{a}$ & $1.045 \mathrm{f}$ \\
\hline & \multirow{6}{*}{ FL } & CK & $0.224 c$ & $0.872 \mathrm{c}$ & $0.744 \mathrm{c}$ & $2.899 \mathrm{c}$ & $0.200 \mathrm{c}$ & $71.9 \mathrm{c}$ & $0.439 \mathrm{c}$ & $0.866 \mathrm{~d}$ \\
\hline & & $\mathrm{Zn} 1$ & $0.228 \mathrm{~d}$ & $0.933 \mathrm{e}$ & $0.756 \mathrm{e}$ & $3.093 \mathrm{e}$ & $0.211 \mathrm{~d}$ & $73.7 \mathrm{e}$ & $0.455 d$ & $0.828 \mathrm{~b}$ \\
\hline & & $\mathrm{Zn} 2$ & $0.232 \mathrm{e}$ & $1.002 \mathrm{f}$ & $0.768 \mathrm{f}$ & $3.314 \mathrm{f}$ & $0.217 \mathrm{e}$ & $75.0 \mathrm{f}$ & $0.472 \mathrm{e}$ & $0.779 a$ \\
\hline & & $\mathrm{Zn} 3$ & $0.226 \mathrm{~d}$ & $0.914 \mathrm{~d}$ & $0.752 \mathrm{~d}$ & $3.031 \mathrm{~d}$ & $0.205 \mathrm{~cd}$ & $72.9 \mathrm{~d}$ & $0.452 d$ & $0.841 \mathrm{c}$ \\
\hline & & $\mathrm{Zn} 4$ & $0.221 \mathrm{~b}$ & $0.830 \mathrm{~b}$ & $0.734 b$ & $2.758 \mathrm{~b}$ & $0.194 b$ & $70.4 \mathrm{~b}$ & $0.430 \mathrm{~b}$ & $0.897 \mathrm{e}$ \\
\hline & & Zn5 & $0.218 \mathrm{a}$ & $0.797 \mathrm{a}$ & $0.727 \mathrm{a}$ & $2.664 \mathrm{a}$ & $0.185 \mathrm{a}$ & $68.9 \mathrm{a}$ & $0.411 \mathrm{a}$ & $0.948 \mathrm{f}$ \\
\hline
\end{tabular}

Values are mean $\pm \mathrm{SE}(\mathrm{n}=3)$. Different letters in the same column indicate significant difference at the $\mathrm{P}<0.05$ level by Duncan's new multiple range test. SL, BT, FE, and FL represent the seedling, booting, flowering, and filling stages, respectively

Compared with the $\mathrm{CK}$, during the BT stage, after 7 days of $\mathrm{Zn} 2$ treatment, the $\mathrm{Y} 2$, ETR, and qP of 'Jingu 21' increased by $30.9 \%, 17.8 \%$, and $23.1 \%$, respectively, while those of 'Zhangzagu 10 ' increased by $15.0 \%, 9.9 \%$, and $15.5 \%$, respectively. After 7 days of Zn5 treatment, compared with those at CK, the Y2, ETR, and qP of 'Jingu 21' decreased by $25.8 \%, 10.2 \%$, and $17.5 \%$, respectively, while those of 'Zhangzagu 10 ' declined by $12.8 \%, 8.1 \%$, and $15.2 \%$, respectively (Tables 3 and 4 ).

After $\mathrm{Zn}$ treatment, the $\mathrm{qN}$ in both cultivars increased first and then decreased with increase in $\mathrm{Zn}$ concentration, and the level of change differed between cultivars and among periods, which was opposite to the trend of $\mathrm{qP}$. In this index, the $\mathrm{Zn}$ treatment of the same cultivars reached the minimum effect in $\mathrm{Zn} 2$ and gradually increased. The levels of both cultivars from the $\mathrm{Zn} 4$ treatment were both lower than those in $\mathrm{CK}$ and reached significant levels with each treatment. Tables 3 and 4 show that $\mathrm{Zn}$ treatment of the two millet varieties was most obvious during the BT stage.

Compared with $\mathrm{CK}$, after 7 days of $\mathrm{Zn} 2$ treatment, the $\mathrm{qN}$ of 'Jingu 21' during SL, BT, FE, and FL decreased by $20.6 \%, 33.5 \%, 28.6 \%$, and $13.7 \%$ respectively, while 
those of 'Zhangzagu 10' declined by $14.2 \%, 28.4 \%, 16.6 \%$, and $10.0 \%$, respectively (Tables 3 and 4). During the BT stage, the $\mathrm{qP}$ of 'Jingu 21' was as follows: $\mathrm{Zn} 5>\mathrm{Zn} 4>\mathrm{CK}>\mathrm{Zn} 3>\mathrm{Zn} 2>\mathrm{Zn} 1$, and 'Zhangzagu 10' showed a similar trend.

Table 4. Effects of Zn on the chlorophyll fluorescence parameters of 'Jingu 21' at the different growth stages

\begin{tabular}{|c|c|c|c|c|c|c|c|c|c|c|}
\hline Cultivar & Period & Treatment & Fo & Fm & Fv/Fm & Fv/Fo & Y2 & ETR & $\mathbf{q P}$ & qN \\
\hline \multirow{24}{*}{ 'Jingu 21' } & \multirow{6}{*}{ SL } & CK & $0.230 \mathrm{c}$ & $0.881 \mathrm{c}$ & $0.739 \mathrm{c}$ & $2.828 \mathrm{c}$ & $0.201 \mathrm{c}$ & $72.3 \mathrm{c}$ & $0.422 \mathrm{c}$ & $1.162 \mathrm{~d}$ \\
\hline & & $\mathrm{Zn} 1$ & $0.236 \mathrm{~d}$ & $0.966 \mathrm{e}$ & $0.755 \mathrm{~d}$ & $3.086 \mathrm{~d}$ & $0.222 \mathrm{~d}$ & $77.2 \mathrm{e}$ & $0.454 \mathrm{~d}$ & $1.014 \mathrm{~b}$ \\
\hline & & $\mathrm{Zn} 2$ & $0.241 \mathrm{e}$ & $1.010 \mathrm{f}$ & $0.762 \mathrm{e}$ & $3.197 \mathrm{e}$ & $0.250 \mathrm{e}$ & $80.9 \mathrm{f}$ & $0.487 \mathrm{e}$ & $0.922 \mathrm{a}$ \\
\hline & & $\mathrm{Zn} 3$ & $0.235 \mathrm{~d}$ & $0.949 \mathrm{~d}$ & $0.753 \mathrm{~d}$ & $3.041 \mathrm{~d}$ & $0.217 \mathrm{~d}$ & $75.7 \mathrm{~d}$ & $0.449 \mathrm{~d}$ & $1.051 \mathrm{c}$ \\
\hline & & $\mathrm{Zn} 4$ & $0.222 b$ & $0.786 b$ & $0.718 b$ & $2.546 \mathrm{~b}$ & $0.188 b$ & $68.6 \mathrm{~b}$ & $0.387 \mathrm{~b}$ & $1.278 \mathrm{e}$ \\
\hline & & Zn5 & $0.218 \mathrm{a}$ & $0.726 a$ & $0.699 a$ & $2.328 \mathrm{a}$ & $0.175 \mathrm{a}$ & $66.4 \mathrm{a}$ & $0.365 \mathrm{a}$ & $1.379 \mathrm{f}$ \\
\hline & \multirow{6}{*}{ BT } & CK & $0.242 \mathrm{c}$ & $0.794 \mathrm{c}$ & $0.696 c$ & $2.285 \mathrm{c}$ & $0.208 \mathrm{c}$ & $70.6 \mathrm{c}$ & $0.451 \mathrm{c}$ & $1.026 \mathrm{~d}$ \\
\hline & & $\mathrm{Zn} 1$ & $0.250 \mathrm{~d}$ & $0.953 \mathrm{e}$ & $0.737 \mathrm{e}$ & $2.809 \mathrm{e}$ & $0.257 \mathrm{e}$ & $79.0 \mathrm{e}$ & $0.505 \mathrm{e}$ & $0.803 \mathrm{~b}$ \\
\hline & & $\mathrm{Zn} 2$ & $0.255 \mathrm{e}$ & $1.132 \mathrm{f}$ & $0.775 f$ & $3.436 \mathrm{f}$ & $0.273 \mathrm{f}$ & $83.2 \mathrm{f}$ & $0.556 f$ & $0.682 \mathrm{a}$ \\
\hline & & $\mathrm{Zn} 3$ & $0.248 \mathrm{~d}$ & $0.918 \mathrm{~d}$ & $0.730 \mathrm{~d}$ & $2.701 \mathrm{~d}$ & $0.244 \mathrm{~d}$ & $76.9 \mathrm{~d}$ & $0.493 \mathrm{~d}$ & $0.849 \mathrm{c}$ \\
\hline & & $\mathrm{Zn} 4$ & $0.230 \mathrm{~b}$ & $0.697 \mathrm{~b}$ & $0.669 \mathrm{~b}$ & $2.024 \mathrm{~b}$ & $0.175 b$ & $65.2 \mathrm{~b}$ & $0.399 b$ & $1.195 \mathrm{e}$ \\
\hline & & Zn5 & $0.226 \mathrm{a}$ & $0.647 \mathrm{a}$ & $0.651 \mathrm{a}$ & $1.868 \mathrm{a}$ & $0.155 \mathrm{a}$ & $63.5 \mathrm{a}$ & $0.372 \mathrm{a}$ & $1.290 \mathrm{f}$ \\
\hline & \multirow{6}{*}{ FE } & CK & $0.236 \mathrm{c}$ & $0.823 c$ & $0.713 \mathrm{c}$ & $2.485 \mathrm{c}$ & $0.213 c$ & $73.1 \mathrm{c}$ & $0.448 \mathrm{c}$ & $0.917 \mathrm{~d}$ \\
\hline & & $\mathrm{Zn} 1$ & $0.244 d$ & $0.955 \mathrm{e}$ & $0.745 \mathrm{e}$ & $2.922 \mathrm{e}$ & $0.236 \mathrm{e}$ & $77.9 \mathrm{e}$ & $0.490 \mathrm{e}$ & $0.790 \mathrm{~b}$ \\
\hline & & $\mathrm{Zn} 2$ & $0.248 \mathrm{e}$ & $1.097 \mathrm{f}$ & $0.774 \mathrm{f}$ & $3.422 \mathrm{f}$ & $0.259 \mathrm{f}$ & $81.5 \mathrm{f}$ & $0.542 \mathrm{f}$ & $0.655 \mathrm{a}$ \\
\hline & & $\mathrm{Zn} 3$ & $0.241 \mathrm{~d}$ & $0.911 d$ & $0.736 \mathrm{~d}$ & $2.781 \mathrm{~d}$ & $0.227 \mathrm{~d}$ & $75.9 \mathrm{~d}$ & $0.480 \mathrm{~d}$ & $0.824 \mathrm{c}$ \\
\hline & & $\mathrm{Zn} 4$ & $0.230 \mathrm{~b}$ & $0.746 b$ & $0.692 b$ & $2.247 \mathrm{~b}$ & $0.190 \mathrm{~b}$ & $69.1 \mathrm{~b}$ & $0.405 b$ & $1.028 \mathrm{e}$ \\
\hline & & Zn5 & $0.224 \mathrm{a}$ & $0.699 a$ & $0.679 \mathrm{a}$ & $2.114 \mathrm{a}$ & $0.181 \mathrm{a}$ & $67.0 \mathrm{a}$ & $0.387 \mathrm{a}$ & $1.113 \mathrm{f}$ \\
\hline & \multirow{6}{*}{ FL } & $\mathrm{CK}$ & $0.229 \mathrm{c}$ & $0.910 \mathrm{c}$ & $0.748 \mathrm{c}$ & $2.976 \mathrm{c}$ & $0.205 \mathrm{c}$ & $71.1 \mathrm{c}$ & $0.441 \mathrm{c}$ & $0.858 \mathrm{~d}$ \\
\hline & & $\mathrm{Zn} 1$ & $0.235 \mathrm{~d}$ & $1.007 \mathrm{e}$ & $0.767 \mathrm{e}$ & $3.289 \mathrm{e}$ & $0.221 \mathrm{e}$ & $74.7 \mathrm{e}$ & $0.464 \mathrm{~d}$ & $0.775 b$ \\
\hline & & $\mathrm{Zn} 2$ & $0.239 \mathrm{e}$ & $1.087 f$ & $0.780 f$ & $3.547 f$ & $0.236 \mathrm{f}$ & $78.2 \mathrm{f}$ & $0.519 \mathrm{e}$ & $0.741 \mathrm{a}$ \\
\hline & & $\mathrm{Zn} 3$ & $0.233 \mathrm{~d}$ & $0.976 \mathrm{~d}$ & $0.761 \mathrm{~d}$ & $3.187 \mathrm{~d}$ & $0.214 \mathrm{~d}$ & $72.7 \mathrm{~d}$ & $0.459 \mathrm{~d}$ & $0.797 \mathrm{c}$ \\
\hline & & $\mathrm{Zn} 4$ & $0.224 b$ & $0.841 b$ & $0.733 b$ & $2.747 \mathrm{~b}$ & $0.195 b$ & $68.8 \mathrm{~b}$ & $0.423 b$ & $0.921 \mathrm{e}$ \\
\hline & & Zn5 & $0.221 \mathrm{a}$ & $0.800 \mathrm{a}$ & $0.724 \mathrm{a}$ & $2.621 \mathrm{a}$ & $0.184 \mathrm{a}$ & $66.7 \mathrm{a}$ & $0.403 \mathrm{a}$ & $0.995 f$ \\
\hline
\end{tabular}

Values are mean $\pm S E(n=3)$. Different letters in the same column indicate significant difference at the $\mathrm{P}<0.05$ level by Duncan's new multiple range test. SL, BT, FE, and FL represent the seedling, booting, flowering, and filling stages, respectively

\section{Discussion}

\section{Effects of Zn on the physiological characteristics}

Although $\mathrm{Zn}$ is a micronutrient necessary for photosynthesis and plant growth at low concentration, $\mathrm{Zn}$ becomes toxic when its concentration reaches a threshold level (Cunha et al., 2008; Lin and Aarts, 2012). Jat et al. (2007) reported that Zn activates several antioxidant enzymes, such as SOD, POD, and CAT. Saeed et al. reported that SOD, POD, and CAT and free radical scavenging activities in cut-flowers remained maximum with the medium dose of $\mathrm{Zn}\left(6 \mathrm{mg} \mathrm{Zn} \mathrm{kg}^{-1}\right)$. Thus, $\mathrm{Zn}$ applied at $6-8 \mathrm{mg} \mathrm{kg}^{-1}$ imparted greater beneficial effects on growth, production, vase life quality, and antioxidative activities in gladiolus cut flower and further higher application rates 
rendered non-significant improvement (Tariq et al., 2013). In this study, $40 \mathrm{mg} \cdot \mathrm{L}^{-1}$ of $\mathrm{ZnSO}_{4} \cdot 7 \mathrm{H}_{2} \mathrm{O}$ significantly increased the SOD, POD, and CAT activities of 'Jingu 21' and 'Zhangzagu 10' at different stages. However, $80 \mathrm{mg} \cdot \mathrm{L}^{-1}$ of $\mathrm{ZnSO}_{4} \cdot 7 \mathrm{H}_{2} \mathrm{O}$ resulted in SOD, POD, and CAT activities lower than those of CK (Figs. 3-5). Moreover, $40 \mathrm{mg} \cdot \mathrm{L}^{-1}$ of $\mathrm{ZnSO}_{4} \cdot 7 \mathrm{H}_{2} \mathrm{O}$ significantly decreased the MDA content, but $80 \mathrm{mg} \cdot \mathrm{L}^{-1}$ of $\mathrm{ZnSO}_{4} \cdot 7 \mathrm{H}_{2} \mathrm{O}$ increased the MDA content higher than that of CK (Fig. 6).

$\mathrm{Zn}$ plays an important role in the anti-lipid peroxidation of millet. The suitable $\mathrm{Zn}$ concentration can alleviate the peroxidation of membrane lipids and improve the antioxidant activity of foxtail millet (Kakade et al., 2009; Maurya and Kumar, 2014; Hajiboland and Beiramzadeh, 2008). Therefore, the application of a suitable concentration of $\mathrm{Zn}$ to foxtail millet will help improve its resistance to stress. The mechanism of the effect of $\mathrm{Zn}$ on energy metabolism needs further study.

\section{Effects of Zn on pigments}

Pigment is the most important part of photosynthesis. This parameter can reflect the ability of plant light energy conversion to a certain extent, and it will also protect the normal operation of photosynthetic apparatus to some extent (Nouet et al., 2011). The main factors in the pigments are chlorophyll and carotenoids, and $\mathrm{Zn}$ can prevent the oxidation of pigments (Cakmak 2000; Cherif et al., 2010). Pongrac et al. (2009) reported that an appropriate amount of $\mathrm{Zn}$ can increase the chlorophyll content of leaves, but excessive $\mathrm{Zn}$ reduces the chlorophyll content of leaves. This experiment shows that low concentration of $\mathrm{Zn}$ can increase the pigment content, while high concentration treatment will inhibit the pigment content. In 'Jingu 21', the pigment content was as follows $\mathrm{Zn} 2>\mathrm{Zn} 1>\mathrm{Zn} 3>\mathrm{CK}>\mathrm{Zn} 4>\mathrm{Zn} 5$, and 'Zhangzagu 10' showed a similar trend (Tables 1 and 2). Excessive $\mathrm{Zn}$ affected the growth of the seedlings, causing a significant decrease in photosynthetic pigment content and yellowing of the leaves. This phenomenon may be due to the antagonistic effect of $\mathrm{Zn}$ and iron metabolism in plants, and the excessive $\mathrm{Zn}$ content inhibited the absorption of iron by plants (Wirén et al., 1996). Thus, an appropriate amount of Zn concentration can effectively increase the pigment content of the leaves (Kumar and Arora, 2000) and delay the rapid senescence of the foxtail millet.

\section{Effects of photosynthetic gas exchange parameters}

Photosynthesis plays a very important role in plants. This process is the source of plant yield, which is related to plant growth and development. This process involves photoreaction and carbon reaction to convert carbon dioxide and water into organic matter and oxygen, which are the basis for plant survival (Baron et al., 1995; Yruela, 2005). The $\mathrm{Pn}, \mathrm{Gs}$, $\mathrm{Tr}$, and $\mathrm{Ci}$ are important indicators to affect the photosynthesis. Fernàndez-Martínez et al. (2014) reported that the photoprotective and antioxidant responses were enhanced with increasing $\mathrm{Zn}$ concentration, but high $\mathrm{Zn}$ concentration produced high toxicity levels for both clones and resulted in impaired biomass production, photochemical processes, and photosynthesis. The results showed that $\mathrm{Zn}$ treatment could increase Pn, Gs, and Tr and reached maximum levels in Zn2, gradually decreased. From the $\mathrm{Zn} 4$ treatment, these three indices were both lower than those at CK, but $\mathrm{Ci}$ showed an opposite trend of Pn (Figs. 7-10). Although the trends are similar at all times, but the degrees of increase or decrease were not the same. In summary, Zn had a regulatory effect on plant photosynthesis and exhibits different effects depending 
on the application concentration, period, and crop type (Sidhu, 2016; Camargo Gai et al., 2017).

\section{Effects of chlorophyll fluorescence parameters}

The chlorophyll fluorescence parameter is a set of variables or constant values used to describe the photosynthesis mechanism and photosynthetic physiological state of plants. This parameter reflects the "inherent" characteristics of plants and regarded as an intrinsic probe to study the relationship between plant photosynthesis and environment (Lahive et al., 2012). Information on the donor side, receptor side, and reaction center of PSII can be obtained using the chlorophyll fluorescence induction kinetics curve (Appenroth et al., 2001; Wen et al., 2002). Fv/Fm represents the primary light energy conversion efficiency of PSII. Previous studies suggested that Fv/Fm is a sensitive indicator of plant photoinhibition under stress conditions. This ratio is a measure of the maximum ability of primary light energy capture, reflecting the potential maximum photosynthetic abilities of plants (Krivosheeva et al., 1996). Fv/Fo represents the potential activity of PSII, which is more sensitive in reflecting changes in photon conversion efficiency during leaf senescence (Krivosheeva et al., 1996). In this study, the $\mathrm{Fv} / \mathrm{Fm}$ and $\mathrm{Fv} / \mathrm{Fo}$ values increased first and then decreased with the change in $\mathrm{Zn}$ concentration, indicating that low $\mathrm{Zn}$ concentration can enhance photosynthesis, but high $\mathrm{Zn}$ concentration can cause photoinhibition of foxtail millet or damage PSII complex. Y2 reflects the quantum conversion efficiency of photosynthetic electron transport and is the efficiency of PSII light energy capture in case of PSII reaction center shutdown (Longstaff et al., 2002). ETR reflects the apparent electron transfer efficiency under actual light intensity conditions (Longstaff et al., 2002). The results of this experiment indicate that as the Zn concentration increases, Y2 and ETR increased and then decreased. This phenomenon indicated that the low $\mathrm{Zn}$ concentration can enhance photosynthesis, but high $\mathrm{Zn}$ concentration inhibition of photosynthesis decreased the actual quantum yield of the PSII photosynthetic reaction center (Tables 3 and 4).

Photochemical quenching $(\mathrm{qP})$ reflects the quantity of light energy absorbed by the PSII antenna pigment for photochemical electron transport. This parameter is a measure of the oxidation state of the original electron acceptor (QA). This parameter represents the proportion of the open part of the PSII reaction center, which can reflect the electron transfer rate of the electron photosynthetic chain and its efficiency in $\mathrm{CO}_{2}$ fixation $(\mathrm{Mu}$ et al., 2016). Under the experimental conditions, $40 \mathrm{mg} \cdot \mathrm{L}^{-1}$ of $\mathrm{ZnSO}_{4} \cdot 7 \mathrm{H}_{2} \mathrm{O}$ significantly increased the $\mathrm{qP}$ of 'Jingu 21' and 'Zhangzagu 10' in different stages. However, from $80 \mathrm{mg} \cdot \mathrm{L}^{-1}$ of $\mathrm{ZnSO}_{4} \cdot 7 \mathrm{H}_{2} \mathrm{O}$, the $\mathrm{qP}$ was lower than that of the control (Tables 3 and 4). This result indicated that the low $\mathrm{Zn}$ concentration strengthened the electron transfer activity of PSII, while high $\mathrm{Zn}$ concentration decreased the open part of the PSII reaction center, which hindered the photosynthetic electron transfer. The parameter qN reflects the portion of the light energy dissipated in the form of heat that cannot be used for photosynthetic electron transport in the light absorbed by the PSII antenna (Mu et al., 2016; Mikulic and Beardall, 2014). The results showed that qN increased first and then decreased with the increase in $\mathrm{Zn}$ concentration. This parameter indicated that $\mathrm{Zn}$ concentration had an inhibitory effect on the heat loss of millet light energy. This process is beneficial to the accumulation of dry matter in foxtail millet. 


\section{Conclusions}

In summary, low $\mathrm{Zn}$ concentration could promote plant growth and enhance plant antioxidant capacity and photosynthesis. However, high $\mathrm{Zn}$ concentration inhibited plant growth and leaf photosynthesis. 'Jingu 21' changed more than 'Zhangzagu10'. The combination of optimal $\mathrm{Zn}$ spraying period and spraying concentration for the foxtail millet growth was BT and $40 \mathrm{mg} \cdot \mathrm{L}^{-1}$ of $\mathrm{Zn}$. Thus, a theoretical basis for the safe application of $\mathrm{Zn}$ fertilizer on foxtail millet is provided.

The study did not test a larger number of genotypes cultivars and more soil fertility conditions because of the limited experimental conditions. The numbers of test materials and test sites were not sufficiently comprehensive. Multiple materials, multiple points, and multiple years of tests are required to provide a clear direction for the subsequent research.

Acknowledgements. This work was financially supported by the Key Research and Development Project of Shanxi Province (201603D221007-2).

\section{REFERENCES}

[1] Alloway, B. J. (2009): Soil factors associated with zinc deficiency in crops and humans. Environ. Geochem. Hlth. 31: 537-548.

[2] Andersen, E. J., Nepal, M. P. (2017): Genetic diversity of disease resistance genes in foxtail millet (Setaria italica, L.). - Plant Gene 10: 8-16.

[3] Appenroth, K. J., Stöckel, J., Srivastava, A., Strasser, R. J. (2001): Multiple effects of chromate on the photosynthetic apparatus of Spirodela polyrhiza as probed by OJIP chlorophyll a fluorescence. - Environmental Pollution 115: 49-64.

[4] Ardiea, S. W., Khumaida, N., Nur, A., Fauziah, N. (2015): Early identification of salt tolerant foxtail millet (Setaria italica L. Beauv). - Procedia Food Science 3: 303-312.

[5] Bai, Q., Chai, M., Gu, Z., Cao, X., Li, Y., Liu, K. (2009): Effects of components in culture medium on glutamate decarboxylase activity and c-aminobutyric acid accumulation in foxtail millet (Setaria italica L.) during germination. - Food Chemistry 116: $152-157$.

[6] Baron, M., Arellano, J. B., Lopez-Gorge, J. (1995): Copper and photosystem II: a controversial relationship. - Physiol Plant 94: 174-180.

[7] Bouis, H. E., Welch, R. M. (2010): Biofortification a sustainable agricultural strategy for reducing micronutrient malnutrition in the global South. - Crop Sci 50: S20-S32. http://dx.doi.org/10.2135/cropsci2009.09.0531.

[8] Cakmak, I. (2000): Tansley review No. 111. Possible roles of zinc in protecting plant cells from damage by reactive oxygen species. - New Phytologist 146(2): 185-205.

[9] Camargo Gai, A. P., dos Santos, D. S., Vieira, E. A. (2017): Effects of zinc excess on antioxidant metabolism, mineral content and initial growth of Handroanthus impetiginosus (Mart. ex DC.) Mattos and Tabebuia roseoalba (Ridl.) Sandwith. Environmental and Experimental Botany 144: 88-99.

[10] Cambrollé, J., Mancilla-Leyton, J. M., Munoz-Valles, S., Luque, T., Figueroa, M. E. (2012): Zinc tolerance and accumulation in the salt-marsh shrub Halimione portulacoides. - Chemosphere 86: 867-874.

[11] Cambrollé, J., Mancilla-Leytón, J. M., Munoz-Vallés, S., Figueroa-Luque, E., Luque, T., Figueroa, M. E. (2013): Evaluation of zinc tolerance and accumulation potential of the coastal shrub Limoniastrum monopetalum (L.) Boiss. - Environmental and Experimental Botany 85: 50-57. 
[12] Carroll, M. D., Loneragan, J. F. (1968): Response of plant species to concentrations of zinc in solution. I. Growth and zinc content of plants. - Aust. J. Agr. Res. 19: 859-868.

[13] Cherif, J., Derbel, N., Nakkach, M., Bergmannc, H., Jemala, F., Lakhdar, Z. B. (2010): Analysis of in vivo chlorophyll fluorescence spectra to monitor physiological state of tomato plants growing under zinc stress. - Journal of Photochemistry and Photobiology B: Biology 101(3): 332-339.

[14] Cunha, K. C. V., Nascimento, C. W. A., Pimentel, R. M. M., Accioly, M. A., Silva, A. J. (2008): Cadmium and zinc availability, accumulation and toxicity in maize grown in a contaminated soil. - Rev. Bras. Ciênc. Solo 32: 1319-1328.

[15] Drinovec, L., Drobne, D., Jerman, I., Zrimec, A. (2004): Delayed fluorescence of Lemna minor: a biomarker of the effects of copper, cadmium, and zinc. - Bulletin of Environment Contamination and Toxicology 72: 896-902.

[16] Feng, J. (2010): The Characteristics of Migration of $\mathrm{Cu}$ and $\mathrm{Zn}$ in Different Black Soil Farmland. - Northeast Forestry University, Heilongjiang (in Chinese).

[17] Fernàndez-Martínez, J., Zacchini, M., Fernández-Marín, B., García-Plazaola, J. I., Fleck, I. (2014): Gas-exchange, photo- and antioxidant protection, and metal accumulation in I214 and Eridano Populus sp. clones subjected to elevated zinc concentrations. Environmental and Experimental Botany 107: 144-153.

[18] Frankart, C., Eullaffroy, P., Vernet, G. (2002): Photosynthetic responses of Lemna minor exposed to xenobiotics, copper, and their combinations. - Ecotoxicology and Environment Safety 53: 439-445.

[19] Gao, J. (2006): Plant Physiology Experiments Guidance. - Higher Education Press, Beijing (in Chinese).

[20] Gartler, J., Robinson, B., Burton, K., Clucas, L. (2013): Carbonaceous soil amendments to biofortify crop plants with zinc. - Science of the Total Environment 465: 308-313.

[21] Genty, B., Briantais, J.-M., Baker, N. R. (1989): The relationship between the quantum yield of photosynthetic electron transport and quenching of chlorophyll fluorescence. Biochimica et Biophysica Acta - Molecular Cell Research 990: 87-92.

[22] Gibson, R. S. (2006): Zinc: the missing link in combating micronutrient malnutrition in developing countries. - Proc. Nutr. Soc. 65: 51-60.

[23] Gunes, A., Inal, A., Alpaslan, M. (1996): Effect of salinity on stomatal resistance, proline and mineral composition of pepper. - J. Plant Nut. 19: 389-396.

[24] Guo, J. (2014): Effects of Different Concentrations and Different Mineral Elements Filling of Spraying on Physiological Characteristics and Yield of Millet. - Shanxi Agricultural University, Taigu (in Chinese).

[25] Guo, M., Wang, Y., Yuan, X., Dong, S., Wen, Y., Song, X., Guo, P. (2018): Responses of the antioxidant system to fluroxypyr in foxtail millet (Setaria italica, L.) at the seedling stage. - Journal of Integrative Agriculture 17(3): 554-565.

[26] Hacisalihoglu, G., Hart, J. J., Wang, Y.-H., Cakmak, I., Kochian, L. V. (2003): Zinc efficiency is correlated with enhanced expression and activity of $\mathrm{Cu} / \mathrm{Zn}$ superoxide dismutase and carbonic anhydrase in wheat. - Plant Physiol. 131: 595-602.

[27] Hajiboland, R., Beiramzadeh, N. (2008): Growth, gas exchange and function of antioxidant defense system in two contrasting rice genotypes under $\mathrm{Zn}$ and Fe deficiency and hypoxia. - Acta Biol. Szegediensis 52 (2): 283-294.

[28] Hu, H., Sparks, D. (1991): Zinc deficiency inhibits chlorophyll synthesis and gas exchange in 'Stuart' pecan. - Hort Science 26: 267-268.

[29] Jamalomidi, M., Esfahani, M., Carapetian, J. (2006): Zinc and salinity interaction on agronomical traits, chlorophyll and proline content in lowland rice (Oryza sativa, L.) genotypes. - Pak. J. Biol. Sci. 9: 1315-1319.

[30] Jat, R. N., Khandelwal, S. K., Gupta, K. N. (2007): Effect of foliar application of urea and zinc sulphate on growth and flowering parameters in African marigold (Tagetes erecta Linn.). - J. Ornam. Hort. 10 (4): 271-273. 
[31] Kabata-Pendias, A., Pendias, H. (2001): Trace Elements in Soils and Plants. - CRC Press, Boca Ratón, FL.

[32] Kakade, D. K., Rajput, S. G., Joshi, K. I. (2009): Effect of foliar application of 'Fe' and 'Zn' on growth, flowering and yield of China aster (Callistephus chinensis LNees). Asian, J. Hort. 4(1): 138-140.

[33] Khoshgoftarmanesh, A. H., Shariatmadari, H., Karimian, N., Khajehpour, M. R. (2006): Responses of wheat genotypes to zinc fertilization under saline soil conditions. - J. Plant Nut. 29: 1543-1556.

[34] Krivosheeva, A., Tao, D. L., Ottander, C., Wingsle, G., Dube, S. L., Öquist, G. (1996): Cold acclimated and photoinhibition in scots pine. - Planta 200: 296-305.

[35] Kumar, P., Arora, J. S. (2000): Effect of micronutrients on gladiolus. - J. Ornam. Hort. New Ser. 3(2): 91-93.

[36] Lahive, E., O’Halloran, J., Jansen, M. A. K. (2012): Frond development gradients are a determinant of the impact of zinc on photosynthesis in three species of Lemnaceae. Aquatic Botany 101: 55-63.

[37] Lin, Y. F., Aarts, M. G. M. (2012): The molecular mechanism of zinc and cadmium stress response in plants. - Cell. Mol. Life Sci. 69: 3187-3206.

[38] Longstaff, B. J., Kildea, T., Runcie, J. W., Cheshire, A., Dennison, W., Hurd, C. L., Kana, T., Raven, J. A., Larkum, A. W. D. (2002): An in situ study of photosynthetic oxygen exchange and electron transport rate in the marine macroalga Ulva lactuca (Chlorophyta). - Photosynth. Res. 74: 281-293.

[39] Marwood, C., Solomon, K., Greenberg, B. (2001): Chlorophyll fluorescence as a bioindi cator of effects on growth in aquatic macrophytes from mixtures of polycyclic aromatic hydrocarbons. - Environmental Toxicology and Chemistry 20: 890-898.

[40] Mateos-Naranjo, E., Castellanos, E. M., Perez-Martin, A. (2014): Zinc tolerance and accumulation in the halophytic species Juncus acutus. - Environmental and Experimental Botany 100: 114-121.

[41] Maurya, R., Kumar, A. (2014): Effect of micronutrients on growth and corm yield of gladiolus. - Plant Arch. 14 (1): 529-533.

[42] Mayer, J. E., Feiffer, W. H. P., Beyer, P. (2008): Biofortified crops to alleviate micronutrient malnutrition. - Curr. Opin. Plant Biol. 11: 166-170.

[43] Mikulic, P., Beardall, J. (2014): Contrasting ecotoxicity effects of zinc on growth and photosynthesis in a neutrophilic alga (Chlamydomonas reinhardtii) and an extremophilic alga (Cyanidium caldarium). - Chemosphere 112: 402-411.

[44] Moss, D. N., Musgrave, R. B. (1971): Photosynthesis and Crop Production. - Advances in Agronomy 23: 317-336.

[45] Mu, T., Du, H., Zhang, F., Li, Z., Jing, X., Tian, G. (2016): Effect of exogenous selenium on foxtail millet chlorophyll fluorescence characteristic. - Chinese Agricultural Science Bulletin 32(36): 73-77 (in Chinese).

[46] Mutegi, E. M., Kung'u, J. B., Muna, M., Pieter, P., Mugendi, D. N. (2012): Complementary effects of organic and mineral fertilizers on maize production in the smallholder farms of Meru South District, Kenya. - Agricultural Sciences 3(2): 221-229.

[47] Nouet, N., Motte, P., Hanikenne, M. (2011): Chloroplastic and mitochondrial metal homeostasis. - Trends in Plant Science 16(7): 395-404.

[48] Noulas, C., Tziouvalekas, M., Karyotis, T. (2018): Zinc in soils, water and food crops. Journal of Trace Elements in Medicine and Biology. https://doi.org/10.1016/j.jtemb.2018.02.009.

[49] Pongrac, P., Zhao, F., Razinger, J., Zrimec, A., Regvar, M. (2009): Physiological responses to $\mathrm{Cd}$ and $\mathrm{Zn}$ in two $\mathrm{Cd} / \mathrm{Zn}$ hyperaccumulating Thlaspi species. Environmental and Experimental Botany 66: 479-486.

[50] Prasad, M., Malec, P., Waloszek, A., Bojko, M., Strzalka, K. (2001): Physiological responses of Lemna trisulca, L. (duckweed) to cadmium and copper bioaccumulation. Plant Science (Limerick) 161: 881-889. 
[51] Prasad, M. N. V., Hagemeyer, J. (eds.) (1999): Heavy Metal Stress in Plants: From Molecules to Ecosystems. - Springer, Berlin.

[52] Rengel, Z., Romheld, V., Marschner, H. (1998): Uptake of zinc and iron by wheat genotypes differing in tolerance to zinc deficiency. - J Plant Physiol 152: 433-438.

[53] Schreiber, U., Schliwa, U., Bilger, W. (1986): Continuous recording of photochemical and non-photochemical chlorophyll fluorescence quenching with a new type of modulation fluorometer. - Photosynthesis Research 10: 51-62.

[54] Schreiber, U., Walz, H., Kolbowski, J. (2003): Propagation of spatial variations of chlorophyll fluorescence parameters in dandeloin leaves induced by spot laser heating. PAM News 1: 1-18.

[55] Sharma, P. N., Tripathi, A., Bisht, S. S. (1995): Zinc requirement for stomatal opening in cauliflower. - Plant Physiol. 107: 751-756.

[56] Sidhu, G. P. S. (2016): Physiological, biochemical and molecular mechanisms of zinc uptake, toxicity and tolerance in plants. - J. Global Biosci. 5(9): 4603-4633.

[57] Silveira, J. A. G., Carvalho, F. E. L. (2016): Proteomics, photosynthesis and salt resistance in crops: an integrative view. - Journal of Proteomics 143: 24-35.

[58] Singh, A., Yashbir, S. S. (2017): Effect of green manures and zinc fertilizer sources on DTPA-extractable zinc in soil and zinc concentration in basmati rice plants at different growth stages. - Pedosphere. DOI: http://dx.doi.org/10.1016/S1002-0160(17)60442-9.

[59] Tariq, S., Imran, H., Ghulam, J., Nadeem, A. A. (2013): Zinc augments the growth and floral attributes of gladiolus, and alleviates oxidative stress in cut flowers. - Scientia Horticulturae 164: 124-129.

[60] Todeschini, V., Lingua, G., D’Agostino, G., Carniato, F., Roccotiello, E., Berta, G. (2011): Effects of high zinc concentration on poplar leaves: a morphological and biochemical study. - Environ. Exp. Bot. 71: 50-56.

[61] Usha, A., Sripriya, G., Chandra, T. S. (1996): The effect of fermentation on the primary nutrients in foxtail millet (Setaria italica). - Food Chemistry 56: 381-384.

[62] Wen, X. G., Qiu, N. W., Lu, Q. T., Lu, C. M. (2002): Enhanced thermo tolerance of photosystem II in salt-adapted plants of the halophyte Artemisia anethifolia. - Planta 220: 486-497.

[63] Wirén, N., Marschner, H., Romheld, V. (1996): Roots of iron-efficient maize also absorb phytosiderophore-chelated zinc. - Plant Physiology 111(4):1119-1125.

[64] Yruela, I. (2005): Copper in plants. - Braz. J. Plant Physiol. 17: 145-146.

[65] Yuan, X. Y., Zhang, L., Huang, L., Yang, H., Zhong, Y., Ning, N., Wen, Y., Dong, S., Song, X., Wang, H., Guo, P. (2017): Spraying Brassinolide improves Sigma Broad tolerance in foxtail millet (Setaria italica L.) through modulation of antioxidant activity and photosynthetic capacity. - Scientific Report 7: 1-9.

[66] Zhao, S., Xu, C., Zou, Q., Meng, Q. (1994): Improvements of method for measurement of Malondialdehvde in plant tissues. - Plant Physiology Communications 30(3): 207-210 (in Chinese).

[67] Zong, X. (2011): Effects of Foliar Application of Zinc on Millet. - Agricultural University of Hebei (in Chinese). 